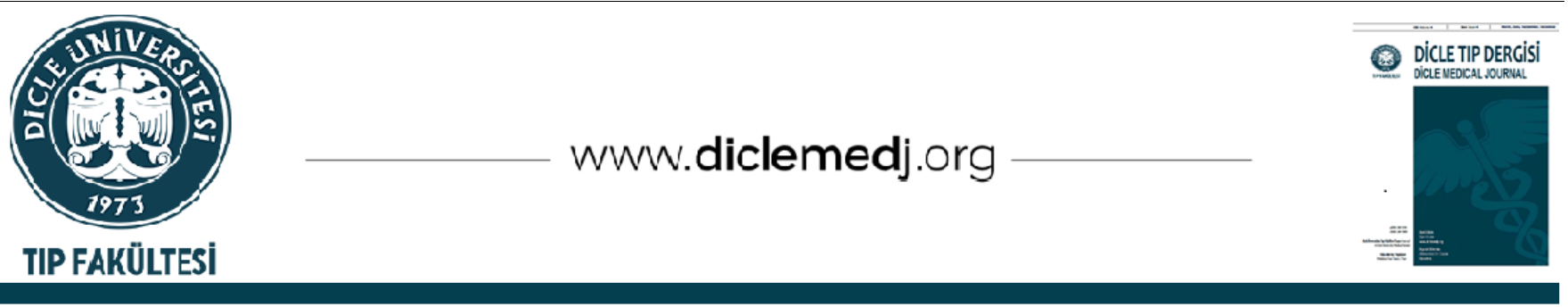

\title{
Arı Sütünün Amiloid Beta ile Deneysel Alzheimer Modeli Oluşturulmuş Sıçanlarda Etkileri
}

\author{
Songül Benzigül ${ }^{i}{ }_{1}$, Saliha Ayşenur Çam ${ }^{i}$, Fatma Uysal ${ }^{i}{ }_{1}$, Seyfullah Oktay Arslan ${ }_{1}$, \\ Hayriye Tatlı Doğan ${ }^{2}{ }_{2}$ \\ 1 Ankara Yıldırım Beyazıt Üniversitesi Tıp Fakültesi Tıbbi Farmakoloji Anabilim Dalı Ankara, Türkiye \\ 2 Ankara Yıldırım Beyazıt Üniversitesi Tıp Fakültesi Tıbbi Patoloji Anabilim Dalı Ankara, Türkiye
}

Geliş: 02.06.2021; Revizyon: 22.08.2021; Kabul Tarihi: 23.08.2021

$\ddot{0} \mathbf{z}$

Giriş: Arı sütünün amiloid beta1-42 enjekte edilerek Alzheimer modeli oluşturulan sıçanlarda, bilişsel işlevin azalmasına ve sinir hücresi inflamasyonuna karşı doza bağlı etkisini araştırmayı amaçladık.

Yöntemler: Çalışmada, 35 adet 4 aylık 280-310 g ağırlığında Wistar-Albino erkek sıçan kullanıldı. Her grupta 7 sıçan olacak șekilde 5 grup oluşturuldu. Aß1-42, hamilton mikroenjektörü ile hipokampüse çift taraflı $4 \mu \mathrm{g} / \mathrm{taraf}$ enjekte edildi. Kontrol grubuna A $\beta 1-42$ yerine, aynı miktarda serum fizyolojik enjekte edildi. Hipokampüs içine A $\beta 1-42$ uygulamasından önceki 7 gün ve sonraki 10 günden sonra, arı sütü sıçan gruplarına sırasıyla $30 \mathrm{mg} / \mathrm{kg}, 100 \mathrm{mg} / \mathrm{kg}, 300$ $\mathrm{mg} / \mathrm{kg}$ mide sondası ile uygulandı. Bu uygulamalar bittikten sonra iki gün sürecek olan Pasif Sakınma testi, sonra beş gün sürecek olan Morris Su Tankı deneyleri uygulandı. Hipokampüs dokularında TNF- $\alpha$ ve IL-1 $\beta$ düzeyleri ölçüldü. İmmünohistokimyasal incelemelerde GFAP ve Iba1 boyanma şiddeti ve yaygınlığı, ayrıca astroglia ve mikroglia hücrelerinin aktive olmuş morfolojiye sahip olup olmamaları esas alındı.

Bulgular: Gruplar karşılaştırıldığında, pasif sakınma testi ve morris su tankı testleri uygulanan sıçanlarda A $\beta 1-42$ uygulamasıyla öğrenme ve hafızada gerileme oluştu. Arı sütü $30 \mathrm{mg} / \mathrm{kg}, 100 \mathrm{mg} / \mathrm{kg}$ ve $300 \mathrm{mg} / \mathrm{kg}$ uygulamasında öğrenme ve hafızada oluşan gerilemenin geri dönüşünde istatistiksel anlamlılık elde edilemedi. Alzheimer hastalığı grubunda gözlenen astrosit ve mikroglia aktivite artışının, $30 \mathrm{mg} / \mathrm{kg}$ grubu hariç diğer tedavi gruplarında baskılandığı görüldü. Hipokampüste TNF- $\alpha$ ve IL-1 $\beta$ düzeylerinin, A $\beta 1-42$ uygulaması ile arttığı görüldü ve tedavi gruplarında arı sütü $30 \mathrm{mg} / \mathrm{kg}$ grubu hariç diğer iki grupta (100 ve $300 \mathrm{mg} / \mathrm{kg}$ ) bu artışın baskılandığını tespit edildi.

Sonuç: Alzheimer modellememizdeki bulgularımıza göre arı sütü uygulaması sonucu, oluşan astoglial ve mikroglial aktivite ve inflamasyon yapıcı sitokin artışının baskılandığı görülmüştür.

Anahtar kelimeler: Alzheimer hastalığı, sıçan, amiloid beta, arı sütü

DOI: $10.5798 /$ dicletip.988081

Correspondence / Yazışma Adresi: Seyfullah Oktay Arslan, Ankara Yıldırım Beyazıt Üniversitesi Tıp Fakültesi Tıbbi Farmakoloji Anabilim Dalı Ankara, Türkiye e-mail: soarslan@gmail.com 


\title{
Effects of royal jelly on rats with amyloid beta in experimental Alzheimer's model
}

\begin{abstract}
Objective: The aim of this study was to evaluate the dose-dependent effect of royal jelly against reduction of cognitive function and neuroinflammation in rats that were injected with amyloid beta1-42 peptide in Alzheimer's model.

Methods: In the study, 35 4-month-old Wistar-Albino male rats weighing 280-310 g were used. 5 groups were formed with 7 rats in each group. The A $\beta 1-42$ peptide was injected $4 \mu \mathrm{g} / \mathrm{side}$ to be bilateral into the hippocampus with the Hamiltonian microinjector. The control group was injected with the same amount of saline, instead of A $1-427$ days before and 10 days after $A \beta 1-42$ administration into the hippocampus, royal jelly was administered to the rat groups at doses of $30 \mathrm{mg} / \mathrm{kg} 100 \mathrm{mg} / \mathrm{kg}$, and $300 \mathrm{mg} / \mathrm{kg}$, respectively, by gastrıc gavaj. After these applications were completed, the Passive Avoidance test, which would last for two days, and then the Morris Water Tank experiments, which would last for five days, were applied. TNF- $\alpha$ and IL-1 $\beta$ levels were measured in the hippocampus tissues. For the evaluation of immunohistochemical staining for immunohistochemical examinations, the severity and extent of staining for GFAP and Iba1, and whether astroglia and microglia cells have activated morphology were taken as basis.
\end{abstract}

Results: When the groups were compared, there was a decline in learning and memory with the application of A $\beta 1-42$ in rats undergoing Passive Avoidance test and Morris Water Tank tests. After administration of royal jelly doses of 30 $\mathrm{mg} / \mathrm{kg}, 100 \mathrm{mg} / \mathrm{kg}$ and $300 \mathrm{mg} / \mathrm{kg}$, there was no improvement in learning and memory decline. The increase in astrocyte and microglia activity observed in the Alzheimer's disease group was suppressed in treatment groups with other doses, except for the as $30 \mathrm{mg} / \mathrm{kg}$ group. TNF- $\alpha$ and IL-1 $\beta$ levels in the hippocampus were increased with the administration of A $\beta 1-42$ peptide, and we found that this increase was suppressed in the treatment groups in the other two groups (100 and $300 \mathrm{mg} / \mathrm{kg}$ ), except for the dose group of royal jelly $30 \mathrm{mg} / \mathrm{kg}$.

Conclusion: According to our findings in our Alzheimer's model, the application of royal jelly was found to suppress the resulting astoglial and microglial activity and inflammatory cytokine increase.

Keywords: Alzheimer's disease, rat, amyloid beta, royal jelly.

\section{GíRiş}

Alzheimer hastalı̆̆ $(\mathrm{AH})$, ilerleyici hafiza ve bilişsel kayıp ile karakterize yaşa bağlı bir hastalıktır. AH, geri dönüşü olmayan sinir hücresi harabiyetine ve beynin sonradan küçülmesine neden olur. Bugüne kadar AH ve diğer sinir hücresi harabiyetinin neden olduğu demanslar için gerçekten etkili bir tedavi tespit edilememiştir ${ }^{1,2}$. Mevcut AH'de kullanılan tedaviler, yalnızca semptomları hafifletir. AH'nin patofizyolojisinin tespit edilmesi, erken teşhis ve spesifik etkili tedavilerin geliştirilmesi için gereklidir. Ancak halen AH'nin kesin nedeni bilinmemektedir. Bununla birlikte araştırmacılar, $\mathrm{AH}$ patogenezinin ana bileşenleri üzerinde bir fikir birliğine varmış olup, patolojik belirtileri arasında amiloid beta $(\mathrm{A} \beta)$ protein kümeleri içeren hücre dişı amiloid plakların ve hücre içinde hiperfosforile tau proteininden oluşan nörofibriler yumakların
(NFY) oluşumunu tespit etmiştir. Ayrıca AH'nin reaktif astroglia, distrofik nörit, nöronların ölümü ve sinaps kaybı gibi durumlar, beynin entorhinal korteks, hipokampus, serebral korteks ve amigdalada meydana gelir. Ancak beynin en fazla zarar gören bölgeleri hipokampus ve serebral kortekstir ${ }^{3,4}$. Hastalığın patolojisinin ne zaman başladığı tespit edilememektedir. AH'nin tespitinde ilerlemeler olmasına rağmen, hastalığın semptomlarını tetikleyen moleküler mekanizmaları gösteren, spesifik biyobelirteçler hakkında kesin bilgi bulunamamıştır. AH'nin en yaygın tipi Sporadik AH'dir, diğer tipi olan Ailevi AH'de hastaların yaklaşık \%5-15'ni ilgilendirir ${ }^{2,5}$.

Arı sütü (AS), genç işçi arıların (Apis mellifera) çene ve hipofaringeal bezlerinden salgılanan beyaz veya sarımsı jelatinimsi bir maddedir6. Araştırmalar, tüm yaşamları boyunca AS ile beslenen kraliçe arıların, bal ve polenlerle 
beslenen işçi arılara göre daha fazla öğrenme ve hafıza gelişimi gösterdiğini tespit etmişlerdir7. AS asidiktir (3.6-4.2), ana bileșeni \%60-70 oranı ile sudur. Ayrıca bileşiminde \%11-23 karbonhidrat, \%9-18 protein, \%4-8 lipitler, az miktarda vitamin, mineral tuzlar ve başka maddeler de mevcuttur. AS'nin kuru madde ağırlığının \%50'sini proteinler, bunların da çoğunu suda çözünmeyen major arı sütü proteinleri oluşturur6,8. Arı sütünün tespit edilmiş çok sayıda biyolojik aktivitesi vardır. Arı sütü biyoaktif bileşiklerin yüksek içeriği sayesinde, insan sağlığı için faydalı olan geniş bir biyolojik etkiye sahiptir. Antihiperkolesterolemik etkiler, antienflamatuvar faaliyetler, antitümör etkileri, antimikrobiyal etkiler, immünomodülatör, antialerjik ve hipoglisemik etkiler gibi etkileri vardır. AS kozmetiklerde, takviye edici gıdalarda ve terapötik ürünlerde kullanılmaktadır 9,10 . AS, kraliçe arı tarafından tüm yaşamları boyunca tüketilen tek besindir. AS'nin kraliçe arının uzun ömür, yüksek doğurganlık, mükemmel öğrenme ve hafıza yeteneğine katkıda bulunduğu öne sürülmektedir7. $\mathrm{Bu}$ nedenle AS'nin, ileri yaşlanmada ve AH'de bilişsel işlevlere olan etkisine bakılmış, $\mathrm{AH}$ patolojisini değiștirebileceği öne sürülmüştür ${ }^{5,9,11}$.

$\mathrm{Bu}$ çalışmamızda $\mathrm{AH}$ gelişiminde $\mathrm{A} \beta$ 'nın önemli bir rol oynadığ ve inflamatuvar cevabı arttırarak nöronal hasar oluşturduğu düşüncesiyle, sıçanlarda hipokampüs içine $A \beta$ enjeksiyonu ile $\mathrm{AH}$ modeli oluşturduk. Antienflamatuvar özelliğinden dolayı birçok hastalıkta denenmiş olan arı sütünün, Alzheimer hastalık modeli (AHM) oluşturulan sıçanlara da uygulayarak hastalık üzerindeki etkilerini inceledik. Hayvanların öğrenme ve hafıza işlevlerinin yanı sıra, hipokampüste astroglial ve mikroglial hücre aktivasyonunda, inflamasyona neden olan sitokinlerde oluşan değişiklikleri inceledik. Kısaca çalışmamız, arı sütünün nöroprotektif etkilerinin varlı̆ğ ve inflamasyonla ilişsisini incelemeye yöneliktir.

\section{YÖNTEMLER}

Bolu Abant İzzet Baysal Üniversitesi Hayvan Yerel Etik Kurulundan 19.04.2018 tarih ve 2018/16 karar numaralı Etik Kurul belgesi alındıktan sonra çalışmaya başlandı. Toplamda 35 adet 4 aylık 280-310 g ağırlığında WistarAlbino erkek sıçan kullanıldı. Her grupta 7 sıçan olacak şekilde 5 grup oluşturuldu. Bunlar sirasıyla kontrol, AH, AS-A (Mide sondası ile 30 mg/kg/gün Arı sütü uygulandı), AS-B (Mide sondası ile $100 \mathrm{mg} / \mathrm{kg} /$ gün Arı sütü uygulandı), AS-C (Mide sondası ile $300 \mathrm{mg} / \mathrm{kg} / \mathrm{gün}$ Arı sütü uygulandı) gruplarıdır. AS, distile su içerisinde çözülerek $+4^{\circ} \mathrm{C}^{\prime}$ de saklandı. AHM oluşturmak amacıyla, A $\beta 1-42$ çözeltisi hazırlanmasında A $1-42$ peptidinin 1 mg'l $^{\prime} 250 \mu \mathrm{l}$ distile suda çözüldü. 7 gün $37^{\circ} \mathrm{C}^{\prime}$ deki etüvde inkübasyona bırakıldı. Hipokampüs içine A $\mathrm{\beta} 1-42$ uygulamasından önceki 7 günden itibaren AS gruplarına belirlenen dozlarda mide sondası ile uyguland, bu uygulama $\mathrm{A} \beta 1-42$ uygulamasından sonraki 10 güne kadar devam etti. Kontrol ve hastalık gruplarına AS yerine, aynı hacimde distile su verildi.

\section{Alzheimer Modelinin Oluşturulması}

Gruplardaki sıçanlara, intraperitonal ketamin/ksilazin $(100 / 5 \mathrm{mg} / \mathrm{kg})$ ile anestezi yapıldı. Hayvanların kafa derisi açıldıktan sonra bregmanın koordinatları bulundu. Hipokampüsün koordinatları Paxinos\&Watson sıçan beyin atlasına göre belirlendii ${ }^{12}$. Kemik dokusu, mikrodelici ile sagital kesiklerden açlldı. Aß1-42 peptidi, Hamilton mikroenjektörü ile hipokampüs içine AP:-3,5 $\mathrm{mm}, \mathrm{ML}: \pm 2.0 \mathrm{~mm}, \mathrm{DV}:-2.8 \mathrm{~mm}$ koordinatlarında çift taraflı $1 \mu \mathrm{l} /$ taraf enjekte edildi. Kontrol grubuna aynı miktarda serum fizyolojik $1 \mu \mathrm{l} / \mathrm{dk}$ hızında enjekte edildi. Sonrasında kesi yeri 3/0 mm cerrahi ipliği kullanılarak kapatıldı. 


\section{Davranış Deneyleri}

AS ve distile su uygulamaları bittikten sonra Pasif sakınma testi (PST), sonrasında Morris su tankı (MST) deneyleri uygulandı. PST'de sıçan ilk gün aydınlık bölmeye 20 saniye bırakıldı, sonra giyotin kapı açıldı, hayvanın karanlık bölmeye geçme süresi not edildi. 60 saniyede geçmeyen, deney dışı bırakıldı. Hayvan karanlık bölmeye geçtiğinde kapı kapatıldı, 0,5 mA elektrik şoku uygulandı. Deneyden 24 saat sonra hayvan tekrar aydınlık bölmeye bırakıldı ve giyotin kapı açıldı. 300 saniyeye kadar hayvanların karanlık bölgeye geçme süresi not alındı. Bu sürede geçmeyenler öğrenmiş kabul edildi.

MST testinde daha önceki çalıșmalarda uygulanmış MST test düzeneği kuruldu'13. Tüm hayvanlar sırayla aynı noktalardan birakıldı, bilgisayara bağlı olan kameranın algılamasıyla deney otomatik olarak başlayarak, 90 saniye boyunca hayvanın hareketleri kaydedildi. Belirlenen süre içerisinde platformu bulamayan sıçanlara, platformun yeri gösterilerek 20 saniye platform üzerinde kalmaları sağlandı. Dört günün sonunda, 20 defa platformu bulma alıștırmaları yapılmış olan sıçanlar beşinci günde teste alındı. Testte platform kaldırılarak tanka bırakılan hayvanlar 60 saniye yüzdürüldü ve program tarafından önceden platformun olduğu kadranda geçirilen süre kaydedildi.

Davranış deneylerinden sonra, intramüsküler ketamin/ksilazin (100/5 mg/kg) ile anestezi yapılan sıçanların dokuları alındı. Beyin dokuları çıkarılarak sağ hemisfer hipokampüsü biyokimyasal analizler için PBS ile dolu kaplara, sol hemisfer histolojik incelemeler için formol ile dolu kaplara konuldu. Sonrasinda beyin dokuları $-80^{\circ} \mathrm{C}^{\prime}$ de muhafaza edildi.

\section{Proenflamatuvar Sitokin Ölçümleri}

Sıçanların hipokampüslerinde ELISA kitleri kullanılarak TNF- $\alpha$ ve IL-1 $\beta$ düzeyleri üreticinin talimatları doğrultusunda standart eğri kullanılarak pg/ml doku olarak hesaplandı.
Hipokampüs dokuları sonikatörde homojenize edildi. Dokular santrifüj edildikten sonra süpernatant alınarak seyreltildi ve kuyucuklara $100 \mu \mathrm{L}$ standart eklenerek kuyucuklar kaplandı. Oda sıcaklığında inkübe edildi. 4 defa yıkama solüsyonu ile yıkandı. Ardından kuyucuklar boşaltıldı. $100 \mu \mathrm{L}$ biyotinlenmiş TNF- $\alpha$ ve IL-1 $\beta$ Deteksiyon Antikoru her bir kuyucuğa eklendi. Plak hafifçe çalkalanarak oda sıcaklığında inkübe edildi. Kuyucuklardaki sıvı uzaklaştırılarak yıkama işlemi tekrarlandı. 100 $\mu \mathrm{L}$ HRP-Streptavidin solüsyonu kuyucuklara eklendi ve yavaşça çalkalanarak oda sıcaklığında inkübe edildikten sonra yıkama işlemi tekrarlandı. $100 \mu \mathrm{L}$ TMB tek-basamak substrat reaktifi her bir kuyucuğa eklendi ve karanlıkta çalkalanarak inkübe edildi. $50 \mu \mathrm{L}$ Stop Solüsyonu kuyucuklara eklendi ve 450 nm'de okuma yapıldı.

\section{İmmünohistokimyasal İncelemeler}

Formalin fikse parafine gömülü beyin dokularından $3 \mathrm{~mm}$ kalınlığında kesitler hazırlandı. Kesitler etüvde $72^{\circ} \mathrm{C}^{\prime}$ de bekletildi. Antikorlar; Iba1 (İyonize Kalsiyum Bağlayıcı Adaptör Molekülü1) (1:8000), GFAP (Glial Fibriler Asidik Protein) (1:100) oranında seyreltildi. Deparafinizasyon ve rehidratasyon işlemi sonrası Iba1 için $40 \mathrm{dk}$ EDTA çözeltisinde, GFAP için $5 \mathrm{dk}$ sitrat çözeltisinde antijen ve retrival işlemi gerçekleştirildi. Ardından yıkama solüsyonuyla 3'er defa yıkandı. Örnekler \%3'lük hidrojen peroksidazda bekletildikten sonra yıkama işlemi tekrarlanıp, primer antikor ile $30 \mathrm{dk}$ inhübasyon yapıldı. Yıkama işleminin ardından lamlara sirasiyla sekonder antikor ve streptavidin peroksidaz damlatılarak 8'er dakika bekletildi. Sonra yıkama işlemi, deiyonize suyla yapıldı. Örnekler sırayla DAB Kromojen damlatıldıktan sonra bekletildi. Yıkama işlemleri sonrası hematoksilende boyanıp, alkol/ksilolden geçirilen kesitler kapatıldı. İmmünohistokimyasal boyanmanın değerlendirilmesinde GFAP ve Iba1 için 
boyanmanın şiddeti ve yaygınlığı, ayrıca astroglia ve mikroglia hücrelerinin aktive olmuş morfolojiye sahip olup olmamaları esas alındı. İmmünhistokimyasal boyanmanın şiddeti ve yaygınlığı 0'dan +3'e kadar sayı ile semikantitatif olarak skorlandl $(0=$ Yok, $+1=\mathrm{Az}$, $+2=0$ rta, $+3=$ Şiddetli).

\section{İstatistik Analizi}

Deney çalışmalarındaki veriler Statistical Package for Social Sciences (SPSS) for Windows 15 programı ile değerlendirildi. Gruplar arası değerlendirmede normal dağılım gösterip göstermemelerine bağlı olarak One-way ANOVA testi ve devaminda Post-hoc Bonferonni testi veya Kruskal Wallis Analizi ve onu takiben Mann-Whitney U Testi kullanılarak yapıldı. Grafikleri oluşturmada GraphPad Prism 7 kullanıldı. İstatistiksel anlamlılık için p $<0.05$ değeri referans alındı.

\section{BULGULAR}

\section{Davranış Deneylerinin Bulguları}

Pasif sakınma deneyinin ilk günü aydınlık kompartmana konan hayvanların karanlık

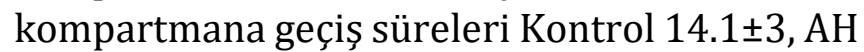

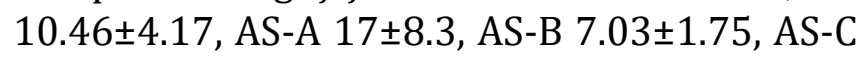
17.5 \pm 6.8 grupları arasında istatistiksel olarak anlamlı bir fark bulunmadı ( $\mathrm{p}>0.05)$. İkinci gün karanlık bölmeye geçiş süreleri Kontrol 256.03 \pm 27.6 , AH 49.54 \pm 11.5 , AS-A 44 \pm 25.57 ,

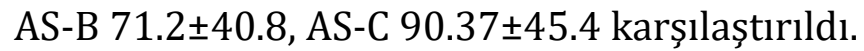
Kontrol grubuna göre tedavi gruplarında değişim oluşmasına rağmen $\mathrm{AH}$ grubu ile istatistiksel olarak anlamlı fark yoktur (Şekil 1).

Morris su tankında platformu bulma süreleri gruplar arası kıyaslandığında ilk gün istatistiksel olarak anlamlı bir farklılık gözlenmedi. Kontrol ile AH grubunun platformu bulma sürelerinde iki, üç ve dördüncü günde de anlamlı bir farklılık gözlenmedi.

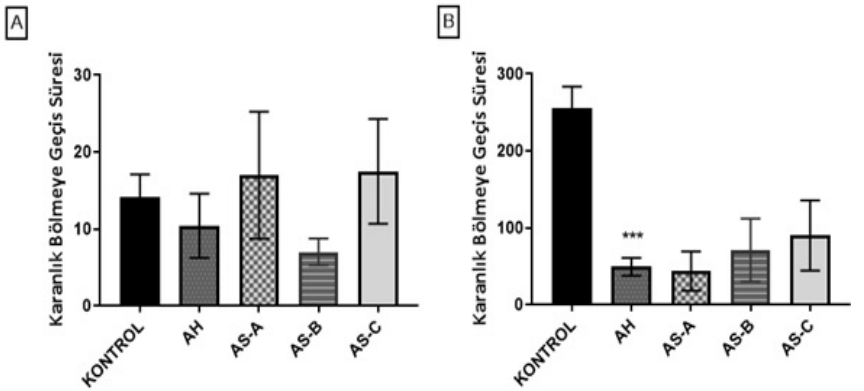

Şekil 1: Pasif Sakınma deney sonuçları. (A) Pasif sakınma testinin ilk gününde deney gruplarının karanlık bölmeye geçiş süresi, (B) Pasif sakınma testinin ikinci gününde deney gruplarının karanlık bölmeye geçiş süresi. $\left(^{* * *} \mathrm{p}<0.001\right.$ Kontrol grubuna göre, $\mathrm{AH}$ grubuna göre kıyaslamayı göstermektedir. AH: Alzheimer Hastalık grubu AS-A: $30 \mathrm{mg} / \mathrm{kg}$, AS-B: 100 $\mathrm{mg} / \mathrm{kg}$, AS-C: $300 \mathrm{mg} / \mathrm{kg}$ Arı sütü uygulanan gruplar

\section{Proenflamatuvar Sitokin Ölçümlerine İlişkin Bulgular}

AH grubu, $196.16 \pm 24$ TNF- $\alpha$ düzeylerinde Kontrol grubuna $51.7 \pm 5.7$ göre yüksek bulundu $(\mathrm{p}<0.001)$. Tedavi grupları AS-B 134.86 \pm 13.6 $(\mathrm{p}<0.05)$, AS-C $131.7 \pm 11.26(\mathrm{p}<0.05)$, TNF- $\alpha$ düzeylerinin ise AH'ye göre düşük olduğu belirlendi. AH grubu 121.93 \pm 11.83 IL-1 $\beta$ düzeylerinin, Kontrol grubuna $37.2 \pm 4.78$ göre yüksek olduğu bulundu $(\mathrm{p}<0.001)$. Tedavi gruplarl AS-B $73.89 \pm 4.96 \quad(\mathrm{p}<0.05), \quad$ AS-C $77.84 \pm 8.8(\mathrm{p}<0.05)$ IL-1 $\beta$ düzeylerinin ise AH'ye göre düşük olduğu belirlendi (Şekil 2).
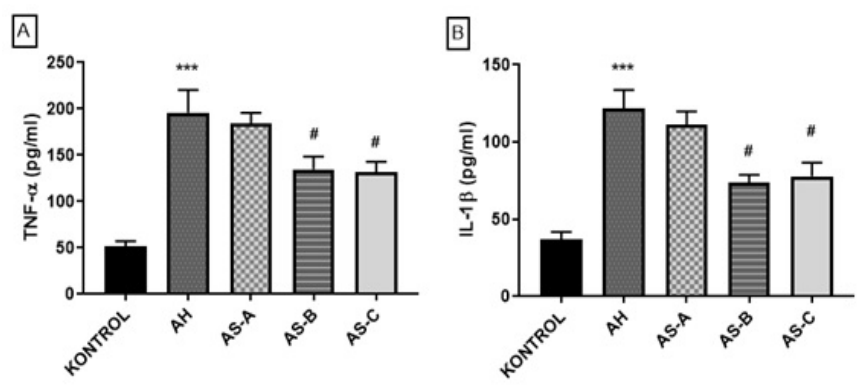

Şekil 2: Hipokampüsde IL-1 $\beta$ ve TNF- $\alpha$ düzeyleri. $\left(^{* * *} \mathrm{p}<0.001\right.$ Kontrol grubuna göre, \#p<0.05, AH grubuna göre kıyaslamayı göstermektedir. AH: Alzheimer Hastalık grubu, AS-A: $30 \mathrm{mg} / \mathrm{kg}$, AS-B: 100 mg/kg, AS-C: 300 mg/kg Arı sütü uygulanan grupla)

\section{İmmünohistokimyasal Bulgular}

GFAP boyama sonuçları incelendiğinde $\mathrm{AH}$ grubunun $2.86 \pm 0.14$ Kontrol grubuna $1.57 \pm 0.2$ göre boyanma skorunun yüksek olduğu gözlendi $(\mathrm{p}<0.001)$. Tedavi grupları AS-B $1.86 \pm 0.26$ 
$(\mathrm{p}<0.05), \quad$ AS-C $\quad 1.83 \pm 0.31 \quad(\mathrm{p}<0.05), \quad$ GFAP boyanma skorunun $\mathrm{AH}$ grubuna göre anlaml ölçüde düşük olduğu gözlendi. Anti-Iba1 ile yapılan immünohistokimyasal boyama ile mikroglia hücreleri boyandı. Mikroglia sayısı ve aktive olan mikroglia oranı göz önüne alınarak semi-kantitatif skorlama yapıldı.

Boyanma skorları incelendiğinde $\mathrm{AH}$ grubunun $2.57 \pm 0.20$ boyanma skorunun Kontrol grubuna $1.29 \pm 0.18$ göre arttığı gözlendi $(\mathrm{p}<0.001)$. Tedavi grupları AS-B 1.71 $\pm 0.29(\mathrm{p}<0.05)$, AS-C $1.67 \pm 0.21$ $(\mathrm{p}<0.05)$, boyanma skorunun $\mathrm{AH}$ grubuna göre anlamlı ölçüde düşük olduğu bulundu (Şekil 3) (Şekil 4) (Şekil 5).
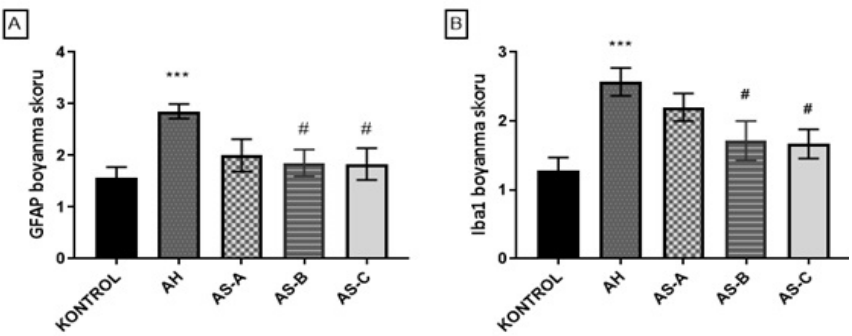

Şekil 3: İmmünohistokimyasal GFAP ve Iba-1 boyanma skorları. $\left({ }^{* * *} \mathrm{p}<0.001\right.$ Kontrol grubuna göre, $\# \mathrm{p}<0.05 \mathrm{AH}$ grubuna göre kıyaslamayı göstermektedir. AH: Alzheimer Hastalık grubu, AS-A: 30 mg/kg, AS-B: 100 mg/kg, AS-C: $300 \mathrm{mg} / \mathrm{kg}$ arı sütü uygulanan gruplar)

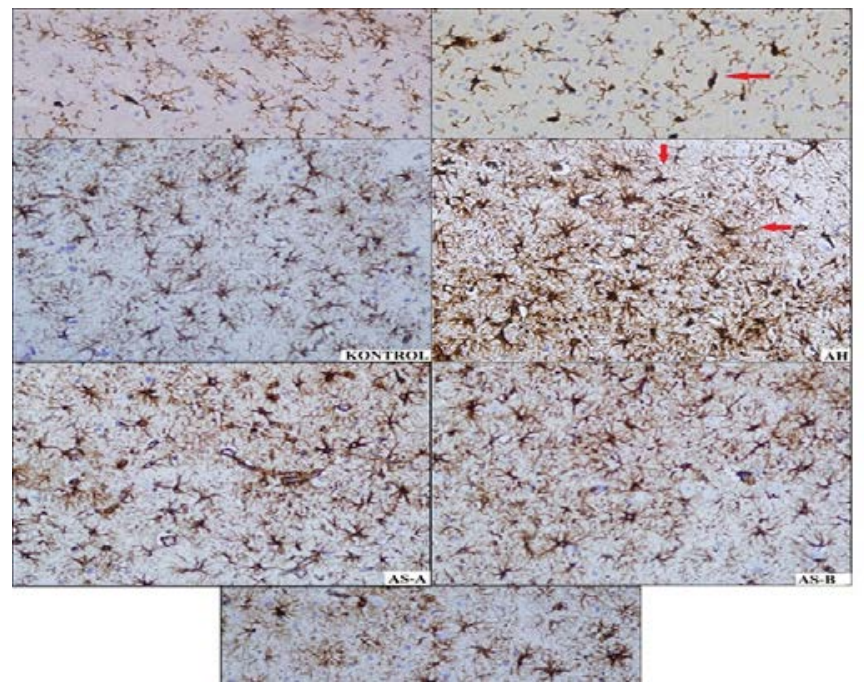

Şekil 4: İmmünohistokimyasal GFAP boyamaları (40 x büyütme). GFAP ile boyanan astroglia hücreleri okla gösterilmiştir. (AH: Alzheimer Hastalık grubu, AS-A: 30 $\mathrm{mg} / \mathrm{kg}$, AS-B: $100 \mathrm{mg} / \mathrm{kg}$, AS-C: $300 \mathrm{mg} / \mathrm{kg}$ arı sütü uygulanan gruplar). GFAP ile boyanan astroglia hücreleri okla gösterilmiştir.

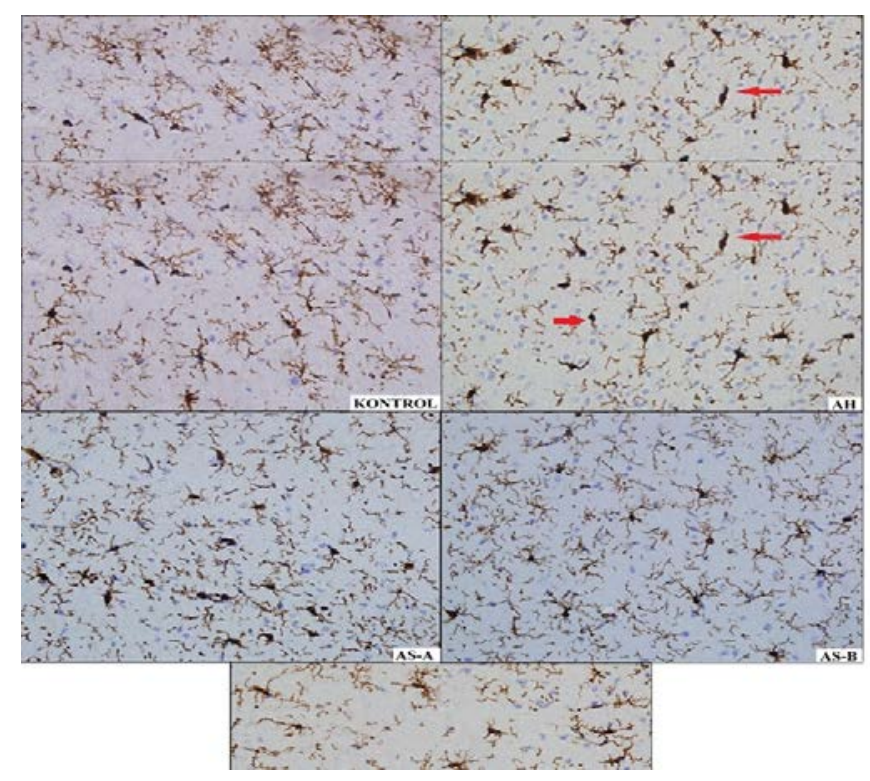

Şekil 5: İmmünohistokimyasal Iba-1 boyamaları (40 x büyütme). Aktive olan mikroglia hücreleri okla gösterilmiştir. (AH: Alzheimer Hastalık grubu, AS-A: 30 $\mathrm{mg} / \mathrm{kg}$, AS-B: $100 \mathrm{mg} / \mathrm{kg}$, AS-C: $300 \mathrm{mg} / \mathrm{kg}$ arı sütü uygulanan gruplar) Aktive olan mikroglia hücreleri okla gösterilmiştir.

\section{TARTIŞMA}

AH oluşturulmuş deneysel modeller, hastalığın patogenezini daha iyi anlamak için kullanılmaktadır. Çalışmalarda transgenik fare modelleri ailevi AH'yi yansıtmak için kullanırken en yaygın tipi olan sporadik AH'nin patolojisinin aydınlatılmasında yetersiz kalmaktadır. Peptit enjekte edilmiş sıçanlar genetik faktörlerin dişında kalan sporadik $\mathrm{AH}$ patolojisine benzer şekilde inflamasyon ve diğer patolojik değişiklikleri taklit ettiği için hayvan modellerinde kullanılmaktadır. AH modeli oluşturmak için sıçan beynine Aß1-42'nin intrahipokampal enjeksiyonu önerilmiştir ${ }^{14,15}$. Yapılan bir çalışmada sıçanlara bilateral hipokampusta A $\beta 1-42$ enjeksiyonu uygulandıktan sonra morris su tankl testi uygulanmış ve nöronal apoptozu uyardığı, bilişsel işlevin bozulduğu görülmüştür. $\mathrm{Bu}$ ve başka çalışmalarda, intrahipokampal $A \beta 1-42$ enjeksiyonunun $\mathrm{AH}$ ile ilişkili bir sinir hücresi harabiyetine neden olduğu doğrulanmıştır ${ }^{16}$. Araştırma bulguları, AS'nin öğrenmeyi ve 
hafızayı korumanın yanı sıra bilișsel davranıș eksikliklerini önleme ve tedavi etme yeteneğini vurgulamaktadır. AH araştırmalarında kemirgenler, doğal yaşlanma ve AHM oluşturularak yaygın şekilde kullanılmaktadır ${ }^{5}$. Ayrıca Klinik öncesi deneyler AS'nin, AHM oluşturulmuş sıçanlarda $A \beta$ sentezini azalttığı, $\mathrm{A} \beta$ klirensini artırarak amiloidogenezin patolojilerini düzelttiğini göstermektedir ${ }^{17}$. Çalışmaların çoğunda hayvanlar, ağızdan veya gavaj yoluyla uzun bir süre (10 gün veya daha fazla) AS ile tedavi edilmiştir. Taradığımız çalışmalarda antienflamatuvar olarak kullanılan AS dozları 25 - $500 \mathrm{mg} / \mathrm{kg}$ vücut ağırlığı/gün arasında olduğu görüldü4,18,19. Arzi ve arkadaşları tarafından yapılan çalışmada, AS'nin $25 \mathrm{mg} / \mathrm{kg}$ dozda antienflamatuvar etkinliğinin olmadığı görülmüşken $50 \mathrm{mg} / \mathrm{kg}$ ve üstünde etkinlik başladığı görülmüş ${ }^{19}$. Çalışmamızda da AS'nin $30 \mathrm{mg} / \mathrm{kg}$ dozda antienflamatuvar etkinliği görülmezken, artan dozlarda; $100 \mathrm{mg} / \mathrm{kg}$ ve $300 \mathrm{mg} / \mathrm{kg}$ dozlarında bu etkinlik görüldü.

Deney protokolümüze göre $A \beta$ enjeksiyonundan 10 gün sonra siçanlarda öğrenme ve bellek işlevlerini test etmek amacıyla yapılan PST, ilk gün karanlık bölmeye geçiş sürelerinde gruplar arasında fark bulunmazken, deneyin ikinci günü $\mathrm{AH}$ grubundaki tüm sıçanların karanlık bölmeye geçtikleri gözlendi. AH grubunun karanlık bölmeye geçiş süreleri Kontrol grubu ile karşılaştırıldığında anlamlı düzeyde düşük olduğu tespit edildi. $A \beta$ enjeksiyonu ile oluşan öğrenme ve hafıza işlevlerindeki bu düşüşün, $\mathrm{A} \beta$ uygulaması ile bilişsel işlevlerde bozulma oluşturduğunu doğruladı. AS, sıçan gruplarına sirasiyla $30 \mathrm{mg} / \mathrm{kg}, 100 \mathrm{mg} / \mathrm{kg}, 300 \mathrm{mg} / \mathrm{kg}$ dozlarda uygulandıktan sonra, PST uygulamamızda iki yüksek dozumuzda bir miktar bilişsel açıdan düzelme gözlendi. Fakat istatiksel olarak anlamlı ölçüde değildi. PST bittikten sonraki gün MST deneyinde, sıçanların etrafa yerleștirilen işaretler yardımıyla platformun yerini öğrenme ve referans belleğini kullanarak platformu bulabilme kabiliyetleri ölçüldü. AH grubundaki sıçanların alıştırma testlerinde platformu bulmak için daha uzun zaman harcamaları, $A \beta$ uygulaması ile bilişsel işlevlerde bozulma oluştuğunu doğruladı. $A \beta$ uygulaması ile oluşan bu bozulma sonrası, AS gruplarına sirasiyla $30 \mathrm{mg} / \mathrm{kg}, 100 \mathrm{mg} / \mathrm{kg}, 300$ $\mathrm{mg} / \mathrm{kg}$ dozlarda uygulanan sıçanlarda, PST'de olduğu gibi bilişsel işlevde bir miktar düzelme oluştu ancak istatiksel açıdan anlamlı değildi. Siçanlarda serebroventrikül içine STZ enjeksiyonu ile olușturulan $\mathrm{AH}$ modelinde, 2 hafta boyunca AS ile oral tedavinin etkisinin morris su labirenti testiyle değerlendirildiği bir çalışmada, uzun süreli AS kullanımının tedaviye olumlu bir etkisi olduğunu göstermiştir ${ }^{4}$. AH modelleri olarak kullanılmış APP/PS1 Fare Modeli 3 ay AS tedavisi uygulandıktan sonra davranış deneylerinden MST testinde ve kademeli PST'ye tabi tutuldular ve farelerin davranışsal bozukluklarının iyileştiği görülmüştür17. Başka bir çalışmada, kısa süreli AS uygulaması (6 gün) yaşlı sıçanlarda uzamsal hafızayı değiştirmediği görülmüş ve kısa süreli kullanımının yeterli olmadığ sonucuna varılmış ${ }^{18}$. Bizim çalışmamızda da $A \beta^{\prime}$ nın yol açtığı bilişsel gerilemenin bir miktar düzeldiği ama anlamlı aralıkta olmadığı görüldü. Sonuçlarımız bu çalışmayı desteklemektedir.

Daha önce yapılan çalışmalarda $A \beta^{\prime}$ nın glial sekresyonu artırdığı görülmüştür. Artan astrosit aktivitesinin doğrudan $A \beta$ üretmediği ama farklı yollardan $A \beta^{\prime}$ nın eliminasyonunu etkilediği tespit edilmiştir. AHM'de, hipokampüs içine $A \beta 1-42$ enjeksiyonu sonrası gelişen reaktif gliozisi ölçmek için immünohistokimyasal Iba-1 (mikroglia için) ve GFAP (astrositler için) boyamalarının yararlı olacağı belirtilmiş ve çalışmalarda kullanılmıştır. Ayrıca mikroglialar sitokinleri (IL-1 $\beta$, TNF- $\alpha$ ) aktive ettikten sonra bu sitokinlerin astrositleri aktive ettiği öne sürülmüştür ${ }^{20,21}$. Çalışmamızda hipokampüs 
içine çift taraflı $A \beta 1-42$ enjeksiyonu ile AHM oluşturulan sıçan gruplarına, AS'nin sırasıyla 30 $\mathrm{mg} / \mathrm{kg}, 100 \mathrm{mg} / \mathrm{kg}, 300 \mathrm{mg} / \mathrm{kg}$ dozlarda oral uygulamasının etkisi hayvanların hipokampüs dokularında proenflamatuvar sitokin IL-1 $\beta$ ve TNF- $\alpha$ düzeylerine bakarak ve Iba- 1 ve GFAP boyamaları yardımıyla mikroglia ve astroglia aktivasyonlarını incelendi.

Iba-1, aktive edilmiş mikroglia için bir immünohistokimyasal belirteç olarak kullanılmaktadır ${ }^{22}$. GFAP, astrositler dahil glia hücreleri için klasik bir belirteçtir ${ }^{23}$. Çalışmamızda mikroglial aktivasyonu araştırmak amacıyla sıçanların hipokampüs kesitlerini, mikroglial aktivasyon belirteci olan anti-Iba1 ile boyadık. Boyanma skorları incelendiğinde $\mathrm{AH}$ grubunun boyanma skorunun, kontrol grubuna göre arttığ gözlendi. Aktive olmuş mikroglia sayısı, AH grubuna göre anlamlı düzeyde daha $\mathrm{az}$ bulunurken, tedavi gruplarında $100 \mathrm{mg} / \mathrm{kg}, 300$ $\mathrm{mg} / \mathrm{kg}$ dozların uygulanmasindan sonra $\mathrm{A} \beta$ tetikli mikroglial aktivasyon artışını anlamlı düzeyde engellediği bulundu. Yapılan bir çalışmada, $A \beta$ uygulaması sonrası anti-CD11b ile yapılan incelemede, çalışmamıza benzer şekilde mikroglia aktivitesinde artış gözlendi ${ }^{24}$.

Astrositler, AH nöroenflamasyonuna ve sinir hücresi harabiyetine neden olurlar. Kemirgenlerde yapılan çalışmalarda, astrositlerin $\mathrm{AH}$ 'ye neden olan nöroenflamatuar ve nörodejeneratif süreçlere doğrudan bir katkısı olduğunu göstermektedir ${ }^{25}$. Üçlü transgenik bir $\mathrm{AH}$ fare modelinin (3xTg-AH) hipokampüsündeki astroglia sayısal yoğunluğunu araştırmak için, belirteç olarak GFAP boyaması kullanılmış̧ ${ }^{26}$. Çalışmamızda astrogliosisi değerlendirmek için, sıçanların hipokampüs kesitlerinde anti-GFAP antikoru boyanmasını kullandık. Tedavi gruplarında 100 $\mathrm{mg} / \mathrm{kg}, 300 \mathrm{mg} / \mathrm{kg}$ AS dozlarının $A \beta$ uygulaması ile artan astoglial aktivasyonu azalttığı görüldü.

Nöroenflamatuvar cevapta artış gösteren enflamatuvar sitokinlerden TNF- $\alpha$ ve IL-1 $\beta$ düzeylerinin, hipokampüse $A \beta$ enjeksiyonu ile arttığını, AS uygulamasının ise bu artıșı azalttığını bulduk. Benzer bir çalıșmada, $A \beta$ enjeksiyonu ile oluşturulan AHM'ye enflamatuvar cevabı baskılayan TGF- $\beta 1$ uygulaması, gliadindeki proenflamatuvar mediyatörlerin (TNF- $\alpha$, IL-1 $\beta$ ve iNOS) artışını önlediği görülmüş̧24. Çalışmamızda A $\mathrm{A} 1-42$ uygulamasıyla, mikroglia ve astrogliaların aktivasyonu ile belirginleşen bilişsel işlevlerdeki düşüş, AS uygulamaları ile düzelmiştir. AS $30 \mathrm{mg} / \mathrm{kg}$ dozunda uygulanması ile $\mathrm{AH}$ patolojisinde anlamlı düzeyde gerileme gözlenmezken, $100 \mathrm{mg} / \mathrm{kg}$ ve $300 \mathrm{mg} / \mathrm{kg}$ dozları uygulanan gruplarda TNF- $\alpha$ ve IL-1 $\beta$ düzeylerinin AH'e grubuna göre düşük olduğu belirlendi ve enflamatuvar cevabın baskılandığı görüldü. AS'deki 10-HDA ile yaplan bir çalışmada, LPS ile uyarılan C57BL/6J fareleri ve mikroglial BV-2 hücreleri Oral olarak 10-HDA verilince TNF- $\alpha$, IL-1 $\beta$ seviyelerinin azaldığı görülmüştür ${ }^{27}$. Kadmiyum kaynaklı kortikal hasar olusturulmuş fare modeline, intragastrik yolla AS'nin iNOS, ROS, NOS, TNF- $\alpha$, IL-1 $\beta$, Bax, kaspaz-3 ve kortikal nöronlarda kadmiyum seviyesini azalttı̆̆ı belirtilmiş ${ }^{28}$.

Sonuç olarak yapılan çalışmalarda görülen; davranış deneyleri ile biyokimyasal ve histolojik incelemeler dikkate alındığında, hipokampüs içi $A \beta$ uygulaması ile sıçanların hipokampüsünde, astrogliosis ve mikrogliosis artışı görülür. Buna paralel TNF- $\alpha$ ve IL-1 $\beta$ sitokinlerinin arttığ 1 ve bu artışın beyinde enflamatuvar cevap oluştuğunu gösterilmektedir. $\mathrm{Bu}$ aşırı enflamatuvar cevabın, $A \beta$ tetikli patolojisini artırarak uzaysal ögrenmede ve hafizada belirgin gerilemeye yol açtı̆̆ davranış testleri ile görülmüştür. Çalışmamızda, AHM oluşturulan sıçanların bilişsel işlevlerindeki düşüş, PST ve MST davranış testleri ile gösterilmiştir. Aynı zamanda hayvanların hipokampüslerinde $A \beta 1$ 42 enjeksiyonunu takiben mikroglia ve astroglia aktivitesindeki artış, 
immünohistokimyasal incelemelerle ortaya konmuş ve bu hücrelerin aktivitelerine paralel olarak IL-1 $\beta$ ve TNF- $\alpha$ sitokin düzeylerinde artıș olduğu görülmüştür. Çalışmamızın davranış testleri bulgularında, öğrenme ve hafıza işlevleri düşüşündeki geri döndürücü etki kısmen görülmekle birlikte istatistiksel anlamlılık yakalanmadı. $\mathrm{Bu}$ sonuçlar bizi, davranış deneyleri bulgularında en sağlıklı veri elde edilmesi için gruplardaki sayının daha yüksek tutulması gerektiği fikrine sahip olmamıza götürdü. AHM ile oluşturulan nörodejenerasyon ilerleyici nitelikte ve tedavide AS uygulama süresinin belirleyici olduğundan uzun vadeli değişimleri gözlemlemek için çalışma süreleri uzatılabilir.

Deneysel olarak oluşturulan AH modellememizdeki bulgularımıza göre AS uygulaması sonucunda, oluşan astoglial ve mikroglial aktivite ve enflamasyon yapıcı sitokin artışının doza bağlı olarak baskılandığı görüldü. $\mathrm{Bu}$ sonuç arı sütünün sinir hücresi enflamasyona karşı etkili olabileceğini düşündürmektedir.

NOT: $\mathrm{Bu}$ makale Ankara Yıldırım Beyazıt Üniversitesi Sağlık Bilimleri Enstitüsü için hazırlanmış olan "Arı Sütünün Amiloid Beta ile Deneysel Alzheimer Modeli Oluşturulmuş Sıçanlarda Etkileri" başlıklı doktora tezimden üretilmiștir.

Etik Kurul Kararı: Bolu Abant İzzet Baysal Üniversitesi Hayvan Yerel Etik Kurulundan 19.04.2018 tarih ve 2018/16 karar numaralı Etik Kurul belgesi alındıktan sonra çalışmaya başlandl.

Çıkar Çatışması Beyanı: Çıkar çatışması bulunmamaktadır.

Finansal Destek: Bu çalışma Ankara Yıldırım Beyazıt Üniversitesi Bilimsel Araştırma Projeleri Birimi tarafından 4990 nolu proje ile desteklenmiştir.
Declaration of Conflicting Interests: The author declare that she has no conflict of interest.

Financial Disclosure: This study is supported by Ankara Yildirim Beyazit University/ Scientific Research Projects Unit (Project No. 4990).

\section{KAYNAKLAR}

1. Javier Olivera-Pueyo CP-V. Dietary supplements for cognitive impairment Introductlon: the Mediterranean diet: Myth or reallty? Actas Esp Psiquiatr. 2017; 45: 37-47.

2. Rabbito A, Dulewicz M, Kulczyńska-Przybik A, Mroczko B. Biochemical Markers in Alzheimer's Disease. Int J Mol Sci. 2020; 21: 1989.

3. Kozlov S, Afonin A, Evsyukov I, Bondarenko A. Alzheimer's disease: As it was in the beginning. Rev Neurosci. 2017; 28: 825-43.

4. Guardia de Souza e Silva T, do Val de Paulo MEF, da Silva JRM, et al. Oral treatment with royal jelly improves memory and presents neuroprotective effects on icv-STZ rat model of sporadic Alzheimer's disease. Heliyon. 2020; 6: e03281.

5. Ali AM, Kunugi H. Royal Jelly as an Intelligent AntiAging Agent-A Focus on Cognitive Aging and Alzheimer's Disease: A Review. Antioxidants. 2020; 9: 937.

6. Fratini F, Cilia G, Mancini S, Felicioli A. Royal Jelly: An ancient remedy with remarkable antibacterial properties. Microbiol Res. 2016; 192: 130-41.

7. Pyrzanowska J, Wawer A, Joniec-maciejak I, et al. Long-term administration of Greek Royal Jelly decreases GABA concentration in the striatum and hypothalamus of naturally aged Wistar male rats. Neurosci Lett. 2018; 675: 17-22.

8. Okamoto I, Taniguchi Y, Kunikata T, et al. Major royal jelly protein 3 modulates immune responses in vitro and in vivo. Life Sci. 2003; 73: 2029-45.

9. Khazaei M, Ansarian A, Ghanbari E. New Findings on Biological Actions and Clinical Applications of Royal Jelly: A Review.J Diet Suppl. 2018; 15: 757-75. 
10. Uçar M. Arı Sütünün Diyabet, Tümör Oluşumu ve Metabolik Sendrom Üzerine Etkisi. Online Türk Sağlık Bilim Derg. 2018; 3: 101-12.

11. Ramadan MF, Al-Ghamdi A. Bioactive compounds and health-promoting properties of royal jelly: A review. J Funct Foods. 2012; 4: 39-52.

12. Paxinos G, Watson C. The Rat Brain in Stereotaxic Coordinates, 3rd ed. New york,Academic Press. 1996. Vol. 191, Journal of Anatomy. WileyBlackwell; 1996. 315-317 p.

13. Morris R. Developments of a water-maze procedure for studying spatial learning in the rat. J Neurosci Methods. 1984; 11: 47-60.

14. Drummond E, Wisniewski T. Alzheimer's disease: experimental models and reality. Acta Neuropathol. 2017; 133: 155-75.

15. McLarnon J, Ryu J. Relevance of A $\beta 1-42$ Intrahippocampal Injection as An Animal Model of Inflamed Alzheimers Disease Brain. Curr Alzheimer Res. 2008; 5: 475-80.

16. Zhang J, Ke K-F, Liu Z, Qiu Y-H, Peng Y-P. Th17 Cell-Mediated Neuroinflammation Is Involved in Neurodegeneration of A $\beta 1$-42-Induced Alzheimer's Disease Model Rats. Vitorica J, editor. PLoS One. 2013; 8: e75786.

17. You M, Pan Y, Liu Y, et al. Royal Jelly Alleviates Cognitive Deficits and $\beta$-Amyloid Accumulation in APP/PS1 Mouse Model Via Activation of the cAMP/PKA/CREB/BDNF Pathway and Inhibition of Neuronal Apoptosis. Front Aging Neurosci. 2019; 10.

18. Pyrzanowska J, Piechal A, Blecharz-Klin K, et al. Administration of Greek Royal Jelly produces fast response in neurotransmission of aged Wistar male rats. J Pre-Clinical Clin Res. 2015; 9: 151-7.

19. Arzi A, Olapour S, Yaghooti H, Karampour NS. Effect of Royal Jelly on Formalin InducedInflammation in Rat Hind Paw. Jundishapur J Nat Pharm Prod. 2015; 10: 8-11.
20. McLarnon JG. Correlated Inflammatory Responses and Neurodegeneration in PeptideInjected Animal Models of Alzheimer's Disease. Biomed Res Int. 2014; 2014: 1-9.

21. Preman $\mathrm{P}$, Alfonso-Triguero $\mathrm{M}$, Alberdi E, Verkhratsky A, Arranz AM. Astrocytes in Alzheimer's Disease: Pathological Significance and Molecular Pathways. Cells. 2021; 10: 540.

22. Hovens I, Nyakas C, Schoemaker R. A novel method for evaluating microglial activation using ionized calcium-binding adaptor protein-1 staining: cell body to cell size ratio. Neuroimmunol Neuroinflammation. 2014; 1: 82.

23. Hol EM, Roelofs RF, Moraal E, et al. Neuronal expression of GFAP in patients with Alzheimer pathology and identification of novel GFAP splice forms. Mol Psychiatry. 2003; 8: 786-96.

24. Chen J-H, Ke K-F, Lu J-H, Qiu Y-H, Peng Y-P. Protection of TGF- $\beta 1$ against Neuroinflammation and Neurodegeneration in A $\beta 1-42$-Induced Alzheimer's Disease Model Rats. PLoS One. 2015; 10 : e0116549.

25. Arranz AM, De Strooper B. The role of astroglia in Alzheimer's disease: pathophysiology and clinical implications. Lancet Neurol. 2019; 18: 406-14.

26. Olabarria M, Noristani HN, Verkhratsky A, Rodríguez JJ. Concomitant astroglial atrophy and astrogliosis in a triple transgenic animal model of Alzheimer's disease. Glia. 2010; 58.

27. You M, Miao Z, Tian J, Hu F. Trans-10-hydroxy-2decenoic acid protects against LPS-induced neuroinflammation through FOX01-mediated activation of autophagy. Eur J Nutr. 2020; 59: 287592.

28. Almeer RS, Kassab RB, AlBasher GI, et al. Royal jelly mitigates cadmium-induced neuronal damage in mouse cortex. Mol Biol Rep. 2019; 46: 119-31. 